\title{
Suniti Kumar Chatterji
}

We deeply regret to announce the death of the President of our Association, Professor Chatterji, in a Calcutta nursing home on $29 t h$ May, 1977, at the age of 87 . His death is a great loss not only to the Association but to linguistics and phonetics in general.

We are grateful to R.K. Bansal, of the Central Institute of English and Foreign Languages, Hyderabad, for the following obituary notice.

Suniti Kumar Chatterji was born at Howrah in West Bengal, India, in November 1890. He was educated at Presidency College, Calcutta, the University of London, and the Sorbonne in Paris. He took his B.A. and M.A. degrees in English at Calcutta (1911 and 1913), getting a first class and the first place in the university in both the examinations. His special subjects for M.A. were Old and Middle English and Germanic and English Linguistics. From 1914 to 1919 he was Assistant Professor of English at Calcutta University, and after that he pursued linguistic studies at the University of London (1919-1921) as a Government of India scholar and obtained a Diploma in Phonetics (1920) and a D.Litt. (1921). At London, where he worked both at University College and the School of Oriental and African Studies, besides Indo-Aryan he also studied Indo-European linguistics, Persian, Old Irish, Old English, and Gothic. On return to India in 1922 he was appointed Khaira Professor of Indian Linguistics and Phonetics at Calcutta University, a position he held till his retirement in 1952, when he was made Emeritus Professor of Comparative Philology. The Government of India honoured him by awarding the titles of Padma Bhushan (1955) and Padma Vibhushan (1963) and appointing him National Professor of India for research in humanities (1965). In 1969 he was elected President of the Sahitya Akademi of India and President of the International Phonetic Association. He was also President of the Asiatic Society, Calcutta. He was awarded an honorary D.Litt. by Calcutta, Delhi, Osmania, Rabindra Bharati and Viswa Bharati Universities in India and the University of Rome.

Suniti Babu, as he was affectionately called by his pupils and admirers, was an acknowledged leader in the field of linguistic studies in India, but not many people know that he was also a wrestler and physical culturist in his youth and this perhaps enabled him to retain his robustness throughout his life. He wrote nearly fifty books and a large number of papers on literary and linguistic subjects in English, Bengali and Hindi. Among his better known books are: The Origin and Development of the Bengali Language (3 volumes), 1926, based on his London D.Litt. thesis; Indo-Aryan 
and Hindi, 1942; Languages and the Linguistic Problem, 1943, in which he discusses the linguistic problem in India and the need for a pan-Indian national language; Languages and Literatures of Modern India, 1963, dealing with the various Indian languages and literatures, their past achievements and present position ; Dravidian, 1963, pointing out the affinities of the Dravidians of India with the primitive pre-Indo-European Mediterranean people; Balts and Aryans in their Indo-European Background, 1968, which discusses the affinity between Sanskrit on the one hand and Lithuanian and Latvian on the other; World Literature and Tagore, 1971, in which he discusses the works of the Indian poet Rabindranath Tagore and places them beside the world's other great classics; and Select Papers, 1972, which contains a collection of thirteen papers written on various occasions.

Suniti Chatterji believed in the unity of man and, as pointed out in a recent article in India, he sought this unity ' in the sum total of human experiences acquired by diverse peoples at different times in different lands'.

(A fuller account of Professor Chatterji's life, with a more extensive bibliography of his works, is contained in Suniti Kumar Chatterji, the Scholar and the Man, edited by Sri Anil Kumar Kanjilal and published by Jijnasa, Calcutta, 1970.) 